\title{
Update on corticosteroids for diabetic macular edema
}

\author{
Stephen G Schwartz' \\ Ingrid $U$ Scott ${ }^{2,3}$ \\ Michael W Stewart ${ }^{4}$ \\ Harry W Flynn Jr' \\ 'Department of Ophthalmology, \\ Bascom Palmer Eye Institute, \\ University of Miami Miller School \\ of Medicine, Miami, FL, ${ }^{2}$ Department \\ of Ophthalmology, ${ }^{3}$ Department of \\ Public Health Sciences, Penn State \\ College of Medicine, Hershey, PA \\ ${ }^{4}$ Department of Ophthalmology, Mayo \\ Clinic Florida, Jacksonville, FL, USA
}

Correspondence: Stephen G Schwartz Department of Ophthalmology, Bascom Palmer Eye Institute, 3880 Tamiami Trail North, Naples, FL 34103, USA

$\mathrm{Tel}+\mathrm{I} 2396593937$

Fax +l 2396593982

Email sschwartz2@med.miami.edu
This article was published in the following Dove Press journal:

Clinical Ophthalmology

8 September 2016

Number of times this article has been viewed

\begin{abstract}
Diabetic macular edema (DME) remains an important cause of visual loss. Although anti-vascular endothelial growth factor (VEGF) agents are generally used as first-line treatments for patients with center-involving DME, there is an important role for corticosteroids as well. Corticosteroids may be especially useful in pseudophakic patients poorly responsive to anti-VEGF therapies, in patients wishing to reduce the number of required injections, and in pregnant patients. Intravitreal triamcinolone acetonide has been used for many years but is not approved for this indication. An extended-release bioerodable dexamethasone delivery system and an extended-release nonbioerodable fluocinolone acetonide insert have both achieved regulatory approval for the treatment of DME. All intravitreal corticosteroids are associated with risks of cataract progression, elevation of intraocular pressure, and endophthalmitis. There is no current consensus regarding the use of corticosteroids, but they are valuable for selected patients with center-involving DME.
\end{abstract}

Keywords: diabetic macular edema, vascular endothelial growth factor, triamcinolone acetonide, dexamethasone, fluocinolone acetonide, randomized clinical trial

\section{Introduction}

Diabetic macular edema (DME) remains a major cause of vision loss in developed countries despite continued improvements in the care of both diabetes mellitus and diabetic retinopathy. ${ }^{1}$ The Early Treatment Diabetic Retinopathy Study reported that immediate focal/grid photocoagulation significantly decreases the likelihood of losing 15 or more letters of best corrected visual acuity (BCVA) due to "clinically significant" DME for up to 3 years. ${ }^{2}$ Based on these results, focal/grid photocoagulation became a standard treatment for DME, though recently introduced intravitreal pharmacotherapies have largely replaced photocoagulation for patients with center-involving DME. ${ }^{3}$

Drugs that inhibit the actions of vascular endothelial growth factor (anti-VEGF agents) have become consensus first-line therapy for the treatment of center-involving DME. In the pivotal Phase III registration trials, monthly intravitreal injections of ranibizumab (Lucentis ${ }^{\circledR}$; Genentech, South San Francisco, CA, USA) ${ }^{4}$ or aflibercept (Eylea $^{\circledR}$; Regeneron, Tarrytown, NY, USA) ${ }^{5}$ improved BCVA significantly more than sham injections/photocoagulation. These trials convinced the US Food and Drug Administration (FDA) to approve each drug for the treatment of center-involving DME accompanied by loss in BCVA. In Phase II randomized clinical trials (RCTs), bevacizumab (Avastin ${ }^{\circledR}$; Genentech) ${ }^{6}$ and pegaptanib (Macugen ${ }^{\circledR}$; Bausch + Lomb, Bridgewater, NJ, USA) ${ }^{7}$ each improved DME, but neither drug has been approved by the FDA for this indication. The Diabetic Retinopathy Clinical Research Network (DRCR.net) performed an RCT and reported that aflibercept, bevacizumab, 
and ranibizumab all effectively improve DME in most patients for at least 2 years. ${ }^{8,9}$

Most patients with DME improve with anti-VEGF treatment and many will also benefit from treatment with corticosteroids. ${ }^{10}$ The mechanism by which corticosteroids improve DME is unclear but several have been postulated. Corticosteroids stabilize and reconstitute the blood-retinal barrier, ${ }^{11}$ favorably alter the Starling's equilibrium by constricting capillaries, and downregulate VEGF expression. ${ }^{12}$ Three fluorinated synthetic corticosteroids that lack mineralocorticoid activity - triamcinolone acetonide, dexamethasone phosphate, and fluocinolone acetonide - are currently used for the treatment of DME. They differ according to their glucocorticoid-receptor binding affinities (dexamethasone $>$ triamcinolone $>$ fluocinolone) and their lipophilicity (triamcinolone $>$ fluocinolone $>$ dexamethasone), characteristics that may partially explain their relative potencies (triamcinolone $=5$, dexamethasone $=25$, fluocinolone $=25$, compared to cortisol $=1$ ).

Corticosteroids also differ according to the proteins that they regulate. Triamcinolone, dexamethasone, and fluocinolone each upregulate over 6,000 proteins in two types of retinal pigment epithelial cells, but only $15 \%-25 \%$ of these proteins are upregulated by all the three corticosteroids. Within trabecular meshwork (TM) 86 cells, dexamethasone upregulates transcripts associated with RNA posttranscriptional modifications, fluocinolone affects lipid metabolism, and triamcinolone affects cell morphology; within TM 93 cells, dexamethasone affects histone methylation, fluocinolone affects the cell cycle, and triamcinolone affects cell adhesion. None of the drugs undergoes intraocular metabolism and clearance from the vitreous proceeds according to first-order pharmacokinetics with elimination half-lives that range from hours (dexamethasone) to days (triamcinolone). ${ }^{13}$ To our knowledge, similar expression data have not been reported from retinal capillary endothelial cells.

The preferred method for the administration of corticosteroids in the treatment of DME is intravitreal injection. Systemic corticosteroids are associated with systemic risks including hyperglycemia. Topical and periocular corticosteroids do not achieve sufficient intraocular penetration to the posterior segment. Intraocular corticosteroids are effective but are associated with increased risks of posterior subcapsular cataract development ${ }^{14}$ and elevation of intraocular pressure (IOP).$^{15}$ Severe ${ }^{16}$ and intractable ${ }^{17,18}$ elevation of IOP constitutes the major impediment to widespread steroid use. The cause of IOP elevation is unknown, but the contribution of genetic factors has long been suspected. ${ }^{19} \mathrm{~A}$ genome-wide association study linked two intergenic quantitative trait loci affecting a novel mucin gene, HCG22 (HLA complex group 22), with increased IOP following treatment with intravitreal triamcinolone acetonide. ${ }^{20}$

Intravitreal corticosteroids are also associated with increased risks of infectious endophthalmitis ${ }^{21}$ and noninfectious endophthalmitis. ${ }^{22}$ These two entities may appear similar clinically and distinguishing between them can be challenging. ${ }^{23}$ Infectious endophthalmitis may be more common with corticosteroids than with anti-VEGF agents. In a series of 406,380 injections, intravitreal triamcinolone acetonide and dexamethasone phosphate were associated with a significantly higher rate of endophthalmitis $(0.13 \%)$ than were anti-VEGF agents $(0.019 \%)$. ${ }^{24}$ Since most patients are treated with a series of intravitreal injections, the cumulative per-patient risk of endophthalmitis is higher than the per-injection risk. Reducing this lifelong cumulative risk by decreasing the number of injections represents one of the major benefits of extended-release drug preparations. ${ }^{25}$

\section{Triamcinolone acetonide}

Intravitreal triamcinolone acetonide, a slow-release crystal structure formulation, has been used to treat DME for many years, ${ }^{26-28}$ but it has been largely replaced by the lower risk anti-VEGF agents. Triamcinolone acetonide remains clinically active for 3 months following a single intravitreal injection. ${ }^{29}$ Triamcinolone is cleared more rapidly from eyes that have undergone vitrectomy, but the clinical responses in these eyes may still be favorable. ${ }^{30} \mathrm{~A}$ single-dose preparation of preservative-free triamcinolone acetonide (Triesence ${ }^{\circledR}$; Alcon Laboratories, Inc., Fort Worth, TX, USA) has been approved by the FDA to enhance visualization of the vitreous during pars plana vitrectomy ${ }^{31}$ and to treat some posterior segment inflammatory diseases, but it has not been approved for the treatment of DME.

The DRCR.net Protocol B RCT compared intravitreal injections of triamcinolone acetonide $1 \mathrm{mg}$, triamcinolone acetonide $4 \mathrm{mg}$, and focal/grid photocoagulation for the treatment of DME. Treatment was allowed every 4 months for persistent or recurrent edema. At the 2-year primary temporal end point, mean BCVA was significantly better in the patients treated with photocoagulation. In the subgroup of patients with poor visual acuity at presentation (20/200-20/320), those treated with triamcinolone acetonide $4 \mathrm{mg}$ (compared to those treated with photocoagulation) had better median improvements in BCVA (+21 vs +7 letters), and rates of $\geq 10$-letter worsening ( $0 \%$ vs $17 \%$ ) and $\geq 10$-letter improvement $(77 \%$ vs $42 \%))^{32}$ 
At 3 years in Protocol B, patients receiving focal/grid photocoagulation had greater mean improvement in BCVA than those receiving triamcinolone acetonide. The prevalence of cataract surgery was highest in patients treated with triamcinolone acetonide $4 \mathrm{mg}(83 \%)$, followed by triamcinolone acetonide $1 \mathrm{mg}$ (46\%), and focal/grid photocoagulation (31\%). IOP increases of $\geq 10 \mathrm{mmHg}$ were most common among patients treated with triamcinolone acetonide $4 \mathrm{mg}$ (33\%), followed by triamcinolone acetonide $1 \mathrm{mg}(18 \%)$, and focal/grid photocoagulation (4\%). ${ }^{33}$

The DRCR.net Protocol I RCT compared ranibizumab plus prompt or deferred photocoagulation with triamcinolone acetonide $4 \mathrm{mg}$ plus prompt photocoagulation and with sham injection plus prompt photocoagulation. Retreatments were based on a complex, predetermined algorithm and the primary temporal end point was at 1 year. Ranibizumab plus either prompt or deferred photocoagulation produced significantly greater mean improvements in BCVA (+9 letters for each group) than did sham injection plus prompt photocoagulation ( +3 letters) and triamcinolone acetonide plus prompt photocoagulation ( +4 letters). Among patients who were pseudophakic at baseline, triamcinolone acetonide plus prompt photocoagulation produced a similar improvement in mean BCVA (+8 letters) as ranibizumab plus prompt ( +8 letters) or deferred (+7 letters) photocoagulation. This suggests that the underperformance of the entire triamcinolone arm may have been due to the development of cataract. ${ }^{34}$

At 2 years in Protocol I, the ranibizumab groups continued to enjoy better visual outcomes than the triamcinolone acetonide group. ${ }^{35}$ Patients in the triamcinolone arm were eligible to receive as-needed ranibizumab from 1.5 to 3 years (depending upon enrollment dates) into the trial, but by 5 years the BCVA improvements in this group still trailed those initially treated with ranibizumab. ${ }^{36}$

The DRCR.net Protocol E RCT compared peribulbar triamcinolone acetonide with laser photocoagulation in patients with mild DME and BCVA of 20/40 or better. Patients were randomized to receive focal/grid photocoagulation, anterior sub-Tenon's triamcinolone acetonide, anterior sub-Tenon's triamcinolone acetonide plus photocoagulation, posterior subTenon's triamcinolone acetonide, or posterior sub-Tenon's triamcinolone acetonide plus photocoagulation. Visual outcomes were similar in all the five groups, suggesting that peribulbar triamcinolone acetonide was ineffective. ${ }^{37}$

Intravitreal triamcinolone acetonide effectively treats DME, but its poor overall performance in clinical trials can probably be attributed to the high incidence of cataracts. Triamcinolone acetonide is still used by many clinicians to treat $\mathrm{DME},{ }^{38}$ particularly in pseudophakic eyes, eyes unresponsive to anti-VEGF therapies, ${ }^{39,40}$ and eyes that present with poor visual acuity.

\section{Dexamethasone}

Off-label, intravitreal injections of dexamethasone phosphate are ineffective for DME, ${ }^{41}$ probably because of rapid clearance from the vitreous. An extended-release bioerodable dexamethasone delivery system (Ozurdex ${ }^{\circledR}$; Allergan, Inc., Irvine, CA, USA), however, has been approved by the FDA for the treatment of DME (Figure 1A and B), macular edema secondary to retinal vein occlusions, ${ }^{42}$ and noninfectious intermediate or posterior uveitis..$^{43}$ Injection of the dexamethasone insert with a single-use, preloaded 22-gauge injector is performed in the outpatient clinic.

In the pivotal Phase III registration RCTs, patients received a $0.35 \mathrm{mg}$ dexamethasone implant, a $0.7 \mathrm{mg}$ dexamethasone implant, or a sham injection, with retreatments using predetermined criteria no more frequently than every 6 months. An improvement in visual acuity of at least 15 letters was reported in $22.2 \%$ of patients treated with the $0.7 \mathrm{mg}$ implant, $18.4 \%$ treated with the $0.35 \mathrm{mg}$ implant, and $12 \%$ treated with sham. ${ }^{44}$ In the subgroup of patients with DME previously treated with focal/grid photocoagulation, anti-VEGF agents, intravitreal triamcinolone acetonide, or a combination of these treatments, an improvement in visual acuity of at least 15 letters was reported in $21.5 \%$ of patients treated with the $0.7 \mathrm{mg}$ implant versus $11.1 \%$ of patients treated with sham. ${ }^{45}$

According to postmarketing clinical data, the dexamethasone delivery system is effective for 3-6 months in most patients. ${ }^{46,47}$ It is equally effective in eyes that have previously undergone vitrectomy ${ }^{48}$ and it was reported to be safe and effective in five pregnant patients. ${ }^{49}$

Several adverse events, particularly cataract development and elevated IOP, are associated with the dexamethasone delivery system. Among patients treated with the $0.7 \mathrm{mg}$ insert (the dose that was eventually approved by the FDA) in the 36-month registration trials, $41.5 \%$ required topical IOP lowering medications, but only $0.3 \%$ required incisional glaucoma surgery. ${ }^{50}$ The dexamethasone delivery system may migrate into the anterior chamber in pseudophakic or aphakic eyes, ${ }^{51}$ which requires surgical removal (Figure 2)..$^{52}$ Less frequently reported complications include endophthalmitis ${ }^{53}$ acute retinal necrosis due to varicella zoster virus, ${ }^{54}$ and retinal and vitreous hemorrhage due to retinal impact during injection. ${ }^{55}$

In a prospective study of eyes with DME, aqueous propermeability factors were measured before and after 
A

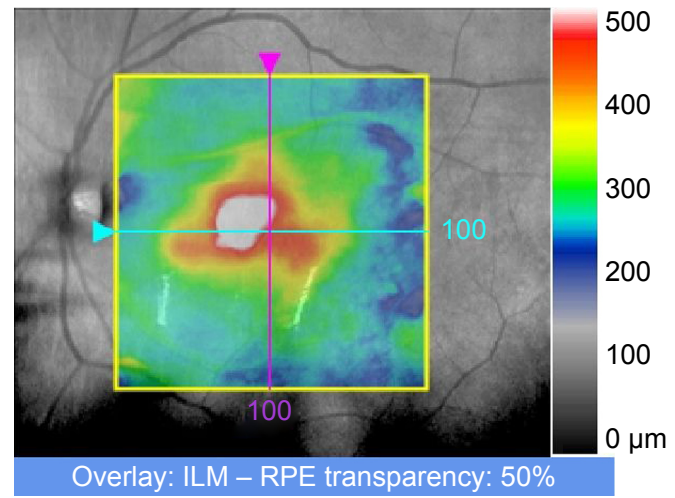

High-definition mode

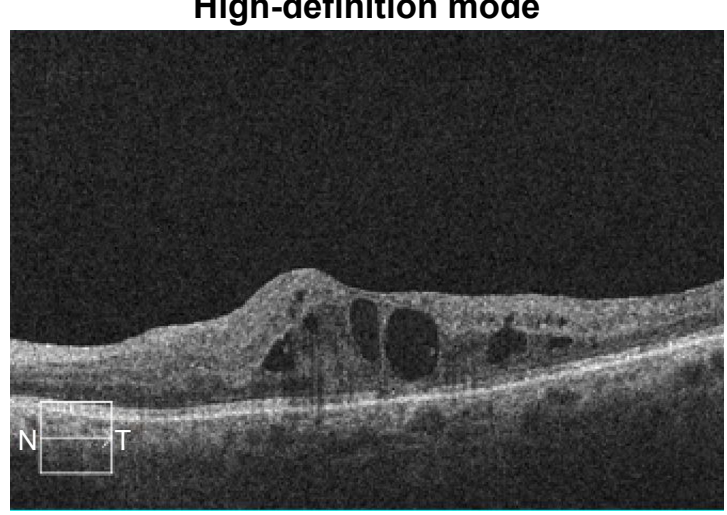

B

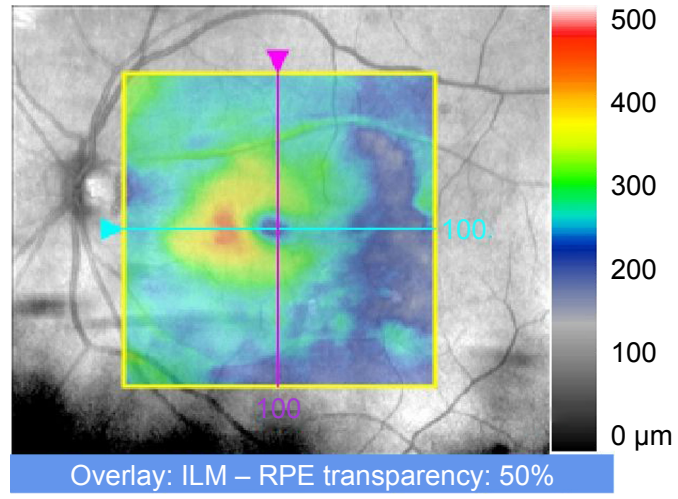

High-definition mode

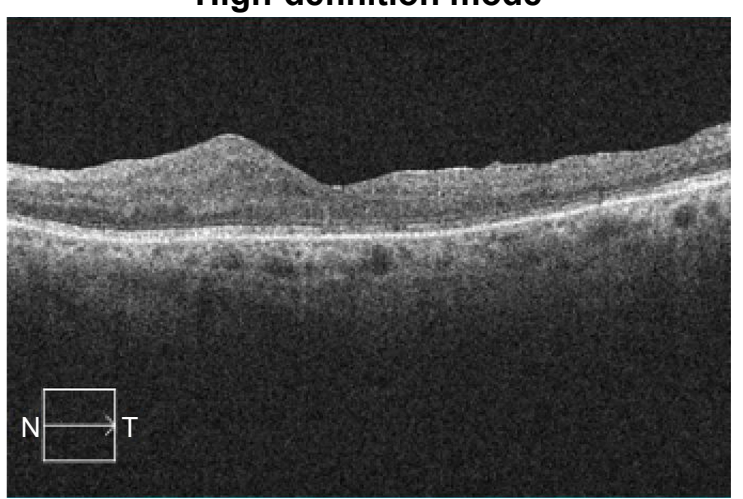

Figure I An 80-year-old male with type 2 diabetes mellitus presented with diabetic macular edema OS and visual acuity of 20/I25.

Notes: (A) Optical coherence tomography revealed diffuse center-involved edema. The patient was treated with an extended-release dexamethasone delivery system. (B) Three months later, optical coherence tomography revealed substantial improvement in edema. Visual acuity improved to $20 / 70$.

Abbreviations: ILM, internal limiting membrane; RPE, retinal pigment epithelium; N, nasal; $\mathrm{T}$, temporal.

dexamethasone insert injections. Significant decreases in aqueous angiopoietin-2, hepatocyte growth factor, and endocrine gland-VEGF concentrations were measured after injection of the insert. ${ }^{56}$

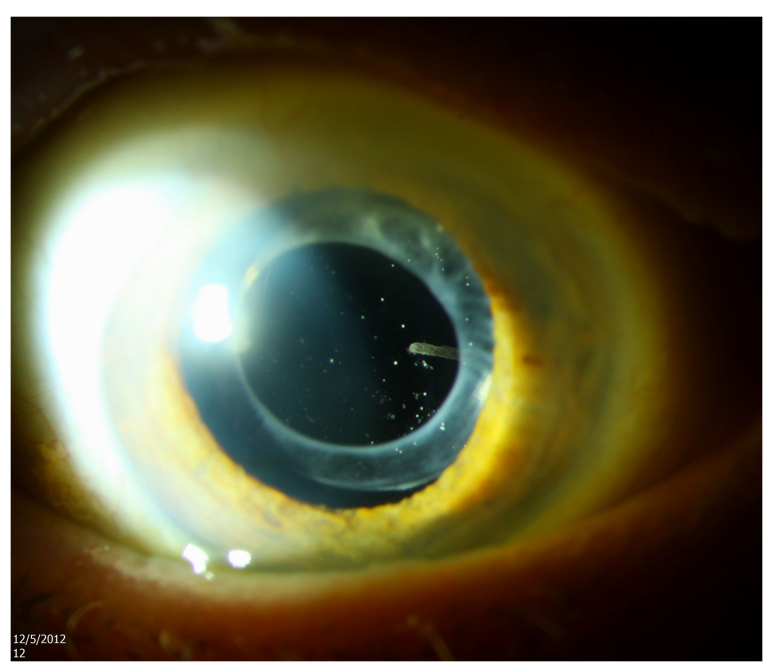

Figure 2 A 92-year-old male presented following treatment with an extendedrelease dexamethasone implant elsewhere several months previously.

Notes: Slit-lamp photography of anterior segment revealed a partially eroded implant in the anterior vitreous, seen nasally. Asteroid hyalosis was also present. The implant was observed.

\section{Fluocinolone acetonide}

Two distinct extended-release formulations of fluocinolone acetonide have been approved by the FDA for intravitreal use: a larger $(0.59 \mathrm{mg})$, nonbioerodable implant (Retisert $^{\mathbb{}}$; Bausch + Lomb), which is implanted surgically through a scleral incision in an operating room; and a smaller $(0.2 \mathrm{mg})$, nonbioerodable insert (Iluvien ${ }^{\circledR}$; Alimera, Alpharetta, GA, USA), which is inserted with a single-use, preloaded 25 -gauge injector in the outpatient clinic.

The larger surgical implant is approved for the treatment of chronic noninfectious posterior segment uveitis. ${ }^{57}$ In a RCT conducted on patients with DME that persisted or recurred following focal/grid photocoagulation, the implant was compared against standard therapy (additional photocoagulation or observation). A BCVA improvement of three or more lines was more common in patients treated with the implant than in those receiving standard therapy at 6 months ( $16.8 \%$ vs $1.4 \%)$, 1 year ( $16.4 \%$ vs $8.1 \%)$, 2 years ( $31.8 \%$ vs $9.3 \%$ ), and 3 years ( $31.1 \%$ vs $20 \%$ ). However, the implant was associated with high rates of IOP elevation and cataract. IOPs of at least $30 \mathrm{mmHg}$ were seen in $61.4 \%$ of implant eyes (vs $5.8 \%$ of standard therapy eyes), and $31.5 \%$ 
of implant patients underwent incisional glaucoma surgery within 4 years. Among phakic eyes, cataract extraction was performed in $91 \%$ (vs $20 \%$ of standard therapy eyes) within 4 years. ${ }^{58}$ Based on these disappointing results, the implant was not approved for the treatment of DME.

The smaller injectable insert has been approved by the FDA for the treatment of DME in patients treated previously with corticosteroids without a clinically significant increase in IOP ${ }^{59}$ though neither the route of corticosteroid delivery nor the duration of treatment is specified on the label. A single insert is effective for up to 3 years. ${ }^{60}$

In the pivotal Phase III registration RCTs, patients with persistent DME after focal/grid photocoagulation were randomized to receive a $0.2 \mu \mathrm{g} /$ day insert, a $0.5 \mu \mathrm{g} /$ day insert, or sham injection. At 2 years, 15-letter improvements in BCVA were achieved in $28.7 \%$ of patients treated with the $0.2 \mu \mathrm{g} /$ day insert (which was eventually FDA approved), $28.6 \%$ with the $0.5 \mu \mathrm{g} /$ day insert, and $16.2 \%$ with sham injection. ${ }^{61}$ Among patients receiving the $0.2 \mu \mathrm{g} /$ day insert, 38.4\% were treated with IOP-lowering medication (vs $14.1 \%$ of sham-treated patients) and $4.8 \%$ were treated with incisional glaucoma surgery (vs $0.5 \%$ of sham-treated patients) within 3 years. ${ }^{62}$ The rates of incisional glaucoma surgery in patients previously treated and not treated with triamcinolone acetonide were $0 \%$ and $6.1 \%$, respectively, ${ }^{63}$ suggesting that restricting the implant to patients known to be nonresponders would improve outcomes and decrease complication rates. A review of fundus photographs obtained during the trials concluded that clinically significant glaucomatous optic nerve damage was not associated with IOP elevation. ${ }^{64}$

Similar to the dexamethasone delivery system, the fluocinolone insert may migrate into the anterior chamber ${ }^{65}$ and require surgical repositioning. ${ }^{66}$

\section{Summary}

Currently, surgeons have three intravitreal corticosteroid options for the treatment of DME: the dexamethasone delivery system, the fluocinolone acetonide insert, and off-label intravitreal triamcinolone acetonide (Table 1). All three agents, as well as the larger fluocinolone acetonide surgical implant, are associated with risks of cataract progression and IOP elevation (Table 2). There is no current consensus regarding the indications for intravitreal corticosteroids, ${ }^{67}$ but they are generally regarded as second-line agents for patients with center-involving DME who respond insufficiently to a series of anti-VEGF injections.

Intravitreal corticosteroids are more appropriate for pseudophakic eyes or in patients being considered for cataract surgery in the near future. Corticosteroids may be preferable to anti-VEGF agents in patients who wish to reduce the number of required injections and in pregnant patients who require treatment of the DME before delivery. As corticosteroid use expands and new data emerge from randomized, controlled

Table I Selected randomized clinical trials of intravitreal corticosteroids: efficacy

\begin{tabular}{|c|c|c|}
\hline Trial & Therapies studied & Summary of results \\
\hline $\begin{array}{l}\text { DRCR.net Protocol B, } \\
\text { 2-year results } \\
32\end{array}$ & Triamcinolone vs photocoagulation & Mean BCVA better in patients treated with photocoagulation \\
\hline $\begin{array}{l}\text { DRCR.net Protocol B, } \\
\text { 3-year results }\end{array}$ & Triamcinolone vs photocoagulation & $\begin{array}{l}\text { Greater mean improvement in BCVA in patients treated with } \\
\text { photocoagulation }\end{array}$ \\
\hline $\begin{array}{l}\text { DRCR.net Protocol I, } \\
\text { I-year results } \\
34\end{array}$ & $\begin{array}{l}\text { Triamcinolone plus photocoagulation vs } \\
\text { ranibizumab plus photocoagulation vs sham } \\
\text { injection plus photocoagulation }\end{array}$ & $\begin{array}{l}\text { Ranibizumab plus photocoagulation produced greatest mean } \\
\text { improvements in BCVA (in pseudophakic eyes, ranibizumab similar } \\
\text { to triamcinolone) }\end{array}$ \\
\hline $\begin{array}{l}\text { DRCR.net Protocol I, } \\
\text { 2-year results } \\
35\end{array}$ & $\begin{array}{l}\text { Triamcinolone plus photocoagulation vs } \\
\text { ranibizumab plus photocoagulation vs sham } \\
\text { injection plus photocoagulation }\end{array}$ & $\begin{array}{l}\text { Ranibizumab associated with better visual outcomes than } \\
\text { triamcinolone }\end{array}$ \\
\hline $\begin{array}{l}\text { DRCR.net Protocol I, } \\
\text { 5-year results } \\
36\end{array}$ & $\begin{array}{l}\text { Triamcinolone plus photocoagulation vs } \\
\text { ranibizumab plus photocoagulation vs sham } \\
\text { injection plus photocoagulation }\end{array}$ & $\begin{array}{l}\text { Ranibizumab associated with better visual outcomes than } \\
\text { triamcinolone }\end{array}$ \\
\hline Boyer et $\mathrm{al}^{44}$ & Dexamethasone insert vs sham injection & $\begin{array}{l}\text { 15-letter improvement in BCVA: } 22.2 \% \text { with dexamethasone } 0.7 \mathrm{mg} \text {, } \\
18.4 \% \text { with dexamethasone } 0.35 \mathrm{mg}, 12 \% \text { with sham }\end{array}$ \\
\hline Augustin et $\mathrm{al}^{45}$ & $\begin{array}{l}\text { Dexamethasone insert vs sham injection - } \\
\text { subgroup with previous other treatments }\end{array}$ & $\begin{array}{l}\text { I5-letter improvement in BCVA: } 21.5 \% \text { with dexamethasone } 0.7 \mathrm{mg} \text {, } \\
\text { II.I\% with sham }\end{array}$ \\
\hline Pearson et $\mathrm{al}^{58}$ & $\begin{array}{l}\text { Fluocinolone surgical implant vs standard } \\
\text { therapy }\end{array}$ & $\begin{array}{l}\text { Three-line improvement in BCVA vs standard therapy: } 16.8 \% \text { vs } 1.4 \% \\
\text { at } 6 \text { months, } 16.4 \% \text { vs } 8.1 \% \text { at I year, } 31.8 \% \text { vs } 9.3 \% \text { at } 2 \text { years, } 31.1 \% \\
\text { vs } 20 \% \text { at } 3 \text { years }\end{array}$ \\
\hline Campochiaro et $\mathrm{al}^{61}$ & Fluocinolone insert vs sham injection & $\begin{array}{l}\text { I5-letter improvement in BCVA at } 2 \text { years: } 28.7 \% \text { with } 0.2 \mu \mathrm{g} / \text { day } \\
\text { insert, } 28.6 \% \text { with } 0.5 \mu \mathrm{g} / \text { day insert, } 16.2 \% \text { with sham }\end{array}$ \\
\hline
\end{tabular}

Abbreviations: BCVA, best corrected visual acuity; DRCR.net, Diabetic Retinopathy Clinical Research Network. 
Table 2 Selected randomized clinical trials of intravitreal corticosteroids: adverse events

\begin{tabular}{|c|c|c|}
\hline Trial & Therapies studied & Summary of results \\
\hline DRCR.net Protocol B, & Triamcinolone vs & Cataract surgery: $83 \%$ with triamcinolone $4 \mathrm{mg}, 46 \%$ with triamcinolone I mg, \\
\hline 3 -year results 33 & photocoagulation & $\begin{array}{l}31 \% \text { with photocoagulation; IOP increase } \geq 10 \mathrm{mmHg}: 33 \% \text { triamcinolone } 4 \mathrm{mg} \text {, } \\
18 \% \text { triamcinolone } \mathrm{I} \mathrm{mg}, 4 \% \text { with photocoagulation }\end{array}$ \\
\hline Maturi et $\mathrm{al}^{50}$ & $\begin{array}{l}\text { Dexamethasone insert vs } \\
\text { sham injection }\end{array}$ & $\begin{array}{l}\text { With } 0.7 \mathrm{mg} \text { insert: } 41.5 \% \text { topical IOP lowering medications, } 0.3 \% \text { incisional } \\
\text { glaucoma surgery }\end{array}$ \\
\hline Pearson et $\mathrm{al}^{58}$ & $\begin{array}{l}\text { Fluocinolone surgical } \\
\text { implant vs standard therapy }\end{array}$ & $\begin{array}{l}\text { Cataract surgery: } 91 \% \text { with implant, } 20 \% \text { with standard therapy; IOP } \geq 30 \mathrm{mmHg} \text { : } \\
6 \mathrm{I} .4 \% \text { with implant, } 5.8 \% \text { with standard therapy }\end{array}$ \\
\hline Campochiaro et $\mathrm{al}^{62}$ & $\begin{array}{l}\text { Fluocinolone insert vs sham } \\
\text { injection }\end{array}$ & $\begin{array}{l}\text { IOP-lowering medication: } 38.4 \% \text { with } 0.2 \mu \mathrm{g} / \text { day insert, } 14.1 \% \text { with sham; } \\
\text { Incisional glaucoma surgery: } 4.8 \% \text { with } 0.2 \mu \mathrm{g} / \text { day insert, } 0.5 \% \text { with sham }\end{array}$ \\
\hline Parrish et $\mathrm{al}^{63}$ & $\begin{array}{l}\text { Fluocinolone insert vs sham } \\
\text { injection }\end{array}$ & $\begin{array}{l}\text { Incisional glaucoma surgery with } 0.2 \mu \mathrm{g} / \text { day insert: } 6.1 \% \text { not previously treated } \\
\text { with triamcinolone, } 0 \% \text { previously treated with triamcinolone }\end{array}$ \\
\hline
\end{tabular}

Abbreviations: DRCR.net, Diabetic Retinopathy Clinical Research Network; IOP, intraocular pressure.

clinical trials, a consensus regarding their optimal use may ultimately emerge.

\section{Acknowledgment}

This article was partially supported by the NIH Center Core Grant P30EY014801 and Research to Prevent Blindness Unrestricted Grant to the University of Miami.

\section{Disclosure}

The authors report no conflicts of interest in this work.

\section{References}

1. Schwartz SG, Flynn HW Jr, Scott IU. Emerging drugs for diabetic macular edema. Expert Opin Emerg Drugs. 2014;19(3):397-405.

2. Early Treatment Diabetic Retinopathy Study Research Group. Photocoagulation for diabetic macular edema: Early Treatment Diabetic Retinopathy Study Report Number 1. Arch Ophthalmol. 1985;103(12): 1796-1806.

3. Jusufbegovic D, Mugavin MO, Schaal S. Evolution of controlling diabetic retinopathy: changing trends in the management of diabetic macular edema at a single institution over the past decade. Retina. 2015;35(5): 929-934.

4. Nguyen QD, Shah SM, Heier JS, et al. Primary end point (six months) results of the Ranibizumab for Edema of the mAcula in diabetes (READ-2) study. Ophthalmology. 2009;116(11):2175-2181.

5. Korobelnik JF, Do DV, Schmidt-Erfurth U, et al. Intravitreal aflibercept for diabetic macular edema. Ophthalmology. 2014;121(11):2247-2254.

6. Diabetic Retinopathy Clinical Research Network, Scott IU, Edwards AR, et al. A phase II randomized clinical trial of intravitreal bevacizumab for diabetic macular edema. Ophthalmology. 2007;114(10):1860-1867.

7. Cunningham ET Jr, Adamis AP, Altaweel M, et al. A phase II randomized double-masked trial of pegaptanib, an anti-vascular endothelial growth factor aptamer, for diabetic macular edema. Ophthalmology. 2005;112(10):1747-1757.

8. Diabetic Retinopathy Clinical Research Network, Wells JA, Glassman AR, et al. Aflibercept, bevacizumab, or ranibizumab for diabetic macular edema. $N$ Engl J Med. 2015;372(13):1193-1203.

9. Wells JA, Glassman AR, Ayala AR, et al. Aflibercept, bevacizumab or ranibizumab for diabetic macular edema: two-year results from a comparative effectiveness randomized clinical trial. Ophthalmology. 2016; 123(6):1351-1359.

10. Schwartz SG, Flynn HW Jr, Scott IU. Intravitreal corticosteroids in the management of diabetic macular edema. Curr Ophthalmol Rep. 2013;1(3):10.
11. Zhang X, Bao S, Lai D, Rapkins RW, Gillies MC. Intravitreal triamcinolone acetonide inhibits breakdown of the blood-retinal barrier through differential regulation of VEGF-A and its receptors in early diabetic rat retinas. Diabetes. 2008;57(4):1026-1033.

12. Zhang X, Wang N, Schachat AP, Bao S, Gillies MC. Glucocorticoids: structure, signaling and molecular mechanisms in the treatment of diabetic retinopathy and diabetic macular edema. Curr Mol Med. 2014; 14(3):376-384.

13. Edelman JL. Differentiating intraocular glucocorticoids. Ophthalmologica. 2010;224(Suppl 1):225-230.

14. Chu YK, Chung EJ, Kwon OW, et al. Objective evaluation of cataract progression associated with a high dose intravitreal triamcinolone injection. Eye. 2008;22(7):895-899.

15. Smithen LM, Ober MD, Maranan L, Spaide RF. Intravitreal triamcinolone acetonide and intraocular pressure. Am J Ophthalmol. 2004; 138(5):740-743.

16. Quiram PA, Gonzales CR, Schwartz SD. Severe steroid-induced glaucoma following intravitreal injection of triamcinolone acetonide. Am J Ophthalmol. 2006;141(3):580-582.

17. Viola F, Morescalchi F, Staurenghi G. Argon laser trabeculoplasty for intractable glaucoma following intravitreal triamcinolone. Arch Ophthalmol. 2006;124(1):133-134.

18. Agrawal S, Agrawal J, Agrawal TP. Management of intractable glaucoma following intravitreal triamcinolone acetonide. Am J Ophthalmol. 2005;139(3):575-576.

19. Becker B. Intraocular pressure response to topical corticosteroids. Invest Ophthalmol. 1965;4:198-205.

20. Jeong S, Patel N, Edlund CK, et al. Identification of a novel mucin gene HCG22 associated with steroid-induced ocular hypertension. Invest Ophthalmol Vis Sci. 2015;56(4):2737-2748.

21. Moshfeghi DM, Kaiser PK, Scott IU, et al. Acute endophthalmitis following intravitreal triamcinolone acetonide injection. Am JOphthalmol. 2003;136(5):791-796.

22. Fong $\mathrm{AH}, \mathrm{Chan} \mathrm{CK}$. Presumed sterile endophthalmitis after intravitreal triamcinolone (Kenalog) - more common and less benign than we thought? Asia Pac J Ophthalmol. Epub 2016 Apr 11.

23. Roth DB, Flynn HW Jr. Distinguishing between infectious and noninfectious endophthalmitis after intravitreal triamcinolone injection. $\mathrm{Am}$ J Ophthalmol. 2008;146(3):346-347.

24. VanderBeek BL, Bonaffini SG, Ma L. The association between intravitreal steroids and post-injection endophthalmitis rates. Ophthalmology. 2015;122(11):2311-2315.

25. Stewart MW, Flynn HW Jr, Schwartz SG, Scott IU. Extended duration strategies for the pharmacologic treatment of diabetic retinopathy: current status and future prospects. Expert Opin Drug Deliv. Epub 2016 Jun 13.

26. Martidis A, Duker JS, Greenberg PB, et al. Intravitreal triamcinolone acetonide for refractory diabetic macular edema. Ophthalmology. 2002;109(5):920-927. 
27. Jonas JB, Kreissig I, Sofker A, Degenring RF. Intravitreal injection of triamcinolone for diffuse diabetic macular edema. Arch Ophthalmol. 2003; 121(1):57-61.

28. Massin P, Audren F, Haouchine B, et al. Intravitreal triamcinolone acetonide for diabetic diffuse macular edema: preliminary results of a prospective controlled trial. Ophthalmology. 2004;111(2):218-224.

29. Mason JO 3rd, Somaiya MD, Singh RJ. Intravitreal concentration and clearance of triamcinolone acetonide in nonvitrectomized human eyes. Retina. 2004;24(6):900-904.

30. Watanabe A, Tsuzuki A, Arai K, Gekka T, Kohzaki K, Tsuneoka H. Efficacy of intravitreal triamcinolone acetonide for diabetic macular edema after vitrectomy. J Ocul Pharmacol Ther. 2016;32(1):38-43.

31. Dyer D, Callanan D, Bochow T, et al. Clinical evaluation of the safety and efficacy of preservative-free triamcinolone acetonide (Triesence [triamcinolone acetonide injectable suspension] $40 \mathrm{mg} / \mathrm{ml}$ ) for visualization during pars plana vitrectomy. Retina. 2009;29(1):38-45.

32. Diabetic Retinopathy Clinical Research Network. A randomized tria comparing intravitreal triamcinolone acetonide and focal/grid photocoagulation for diabetic macular edema. Ophthalmology. 2008;115(9): 1447-1449.

33. Diabetic Retinopathy Clinical Research Network, Beck RW, Edwards AR, et al. Three-year follow-up of a randomized trial comparing focal/grid photocoagulation and intravitreal triamcinolone for diabetic macular edema. Arch Ophthalmol. 2009;127(3):245-251.

34. Diabetic Retinopathy Clinical Research Network, Elman MJ, Aiello LP, et al. Randomized trial evaluating ranibizumab plus prompt or deferred laser or triamcinolone plus prompt laser for diabetic macular edema. Ophthalmology. 2010;117(6):1064-1077.

35. Elman MJ, Bressler NM, Qin H, et al. Expanded 2-year follow-up of ranibizumab plus prompt or deferred laser or triamcinolone plus prompt laser for diabetic macular edema. Ophthalmology. 2011;118(4): 609-614.

36. Bressler SB, Glassman AR, Almukhtar T, et al. Five-year outcomes of ranibizumab with prompt or deferred laser versus laser or triamcinolone plus deferred ranibizumab for diabetic macular edema. Am J Ophthalmol. 2016;164:57-68.

37. Diabetic Retinopathy Clinical Research Network, Chew E, Strauber S, et al. Randomized trial of peribulbar triamcinolone acetonide with and without focal photocoagulation for mild diabetic macular edema: a pilot study. Ophthalmology. 2007;114(6):1190-1196.

38. Schwartz SG, Flynn HW Jr, Beer P. Intravitreal triamcinolone acetonide use in diabetic macular edema: illustrative cases. Ophthalmic Surg Lasers Imaging. 2010:1-6.

39. Kim JH, Lee TG, Lew YJ. Short-term efficacy of intravitreal triamcinolone acetonide for bevacizumab-resistant diabetic macular edema. Acta Ophthalmol. 2015;93(2):e178-e179.

40. Jeon S, Lee WK. Effect of intravitreal triamcinolone in diabetic macular edema unresponsive to intravitreal bevacizumab. Retina. 2014; 34(8):1606-1611.

41. Chan CK, Mohamed S, Lee VY, et al. Intravitreal dexamethasone for diabetic macular edema: a pilot study. Ophthalmic Surg Lasers Imaging. 2010; 41(1):26-30.

42. Haller JA, Bandello F, Belfort R Jr, et al. Randomized, sham-controlled trial of dexamethasone intravitreal implant in patients with macular edema due to retinal vein occlusion. Ophthalmology. 2010;117(6):1134-1146.

43. Lowder C, Belfort R Jr, Lightman S, et al. Dexamethasone implant for noninfectious intermediate or posterior uveitis. Arch Ophthalmol. 2011; 129(5):545-553

44. Boyer DS, Yoon YH, Belfort R Jr, et al. Three-year, randomized, shamcontrolled trial of dexamethasone intravitreal implant in patients with diabetic macular edema. Ophthalmology. 2014;121(10):1904-1914.

45. Augustin AJ, Kuppermann BD, Lanzetta P, et al. Dexamethasone intravitreal implant in previously treated patients with diabetic macular edema: subgroup analysis of the MEAD study. BMC Ophthalmol. 2015;15:150.

46. Pacella F, Ferraresi AF, Turchetti P, et al. Intravitreal injection of Ozurdex implant in patients with persistent diabetic macular edema, with six-month follow-up. Ophthalmol Eye Dis. 2016;8:11-16.
47. Mantonti F, Pommier S, Meyer F, et al. Long-term efficacy and safety of intravitreal dexamethasone implant for the treatment of diabetic macular edema. Eur J Ophthalmol. Epub 2016 Apr 12.

48. Boyer DS, Faber D, Gupta S, et al. Dexamethasone intravitreal implant for treatment of diabetic macular edema in vitrectomized patients. Retina. 2011;31(5):915-923.

49. Concillado M, Lund-Anderson H, Mathiesen ER, Larsen M. Dexamethasone intravitreal implant for diabetic macular edema during pregnancy. Am J Ophthalmol. 2016;165:7-15.

50. Maturi RK, Pollack A, Uy HS, et al. Intraocular pressure in patients with diabetic macular edema treated with dexamethasone intravitreal implant in the 3-year MEAD study. Retina. 2016;36(6):1143-1152.

51. Stepanov A, Codenotti M, Ramoni A, et al. Anterior chamber migration of dexamethasone intravitreal implant $\left(\right.$ Ozurdex $\left.{ }^{\circledR}\right)$ through basal iridectomy (Ando) in a pseudophakic patient. Eur J Ophthalmol. 2016; 26(3):e52-e54.

52. Khurana RN, Appa SN, McCannel CA, et al. Dexamethasone implant anterior chamber migration: risk factors, complications, and management strategies. Ophthalmology. 2014;121(1):67-71.

53. Esen E, Sizmaz S, Demircan N. Two cases of acute endophthalmitis after intravitreal dexamethasone implant injection. Retin Cases Brief Rep. 2016;10(2):154-156.

54. Kucukevcilioglu M, Eren M, Yolcu U, Sobaci G. Acute retinal necrosis following intravitreal dexamethasone (Ozurdex) implant. Arq Bras Oftalmol. 2015;78(2):118-119.

55. Casati S, Bruni E, Machini G. Retinal and vitreous hemorrhage after traumatic impact of dexamethasone implant in a vitrectomized eye. Eur J Ophthalmol. 2016;26(3):e55-e57.

56. Campochiaro PA, Hafiz G, Mir TA, et al. Pro-permeability factors in diabetic macular edema: the Diabetic Macular Edema Treated with Ozurdex Trial. Am J Ophthalmol. 2016;168:13-23.

57. Jaffe GJ, Martin D, Callanan D, et al. Fluocinolone acetonide implant (Retisert) for noninfectious posterior uveitis: thirty-four-week results of a multicenter randomized clinical study. Ophthalmology. 2006;113(6): 1020-1027.

58. Pearson PA, Comstock TL, Ip M, et al. Fluocinolone acetonide intravitreal implant for diabetic macular edema: a 3-year multicenter, randomized, controlled clinical trial. Ophthalmology. 2011;118(8): $1580-1587$.

59. Schwartz SG, Flynn HW Jr. Fluocinolone acetonide implantable device for diabetic retinopathy. Curr Pharm Biotechnol. 2011;12(3):347-351.

60. Cunha-Vaz J, Ashton P, Iezzi R, et al. Sustained delivery fluocinolone acetonide vitreous implants: long-term benefit in patients with chronic diabetic macular edema. Ophthalmology. 2014;121(10):1892-1903.

61. Campochiaro PA, Brown DM, Pearson A, et al. Long-term benefit of sustained-delivery fluocinolone acetonide vitreous inserts for diabetic macular edema. Ophthalmology. 2011;118(4):626-635.

62. Campochiaro PA, Brown DM, Pearson A, et al. Sustained delivery fluocinolone acetonide vitreous inserts provide benefit for at least 3 years in patients with diabetic macular edema. Ophthalmology. 2012;119(10): 2125-2132.

63. Parrish RK 2nd, Campochiaro PA, Pearson PA, et al. Characterization of intraocular pressure increases and management strategies following treatment with fluocinolone acetonide intravitreal implants in the FAME trials. Ophthalmic Surg Lasers Imaging Retina. 2016;47(5):426-435.

64. Parrish RK 2nd, Traverso CE, Green K, Danis RP; FAME Study Group. Quantitative assessment of optic nerve changes in patients with diabetic macular edema treated with fluocinolone acetonide vitreous implants. Ophthalmic Surg Lasers Imaging Retina. 2016;47(5):418-425.

65. Papastavrou VT, Zambarakji H, Dooley I, Eleftheriadis H, Jackson TL. Observation: fluocinolone implant (Iluvien) implant migration into the anterior chamber. Retin Cases Brief Rep. Epub 2016 Feb 23.

66. El-Ghrably IA, Saad A, Dinah C. A novel technique for repositioning of a migrated Iluvien (fluocinolone acetonide) implant into the anterior chamber. Ophthalmol Ther. 2015;4(2):129-133.

67. Puliafito CA, Cousins SW, Bacharach J, et al. Forming a consensus: data and guidance for physicians treating diabetic macular edema. Ophthalmic Surg Lasers Imaging Retina. 2016;47(4):S4-S15. 


\section{Publish your work in this journal}

Clinical Ophthalmology is an international, peer-reviewed journal covering all subspecialties within ophthalmology. Key topics include: Optometry; Visual science; Pharmacology and drug therapy in eye diseases; Basic Sciences; Primary and Secondary eye care; Patient Safety and Quality of Care Improvements. This journal is indexed on

Submit your manuscript here: http://www.dovepress.com/clinical-ophthalmology-journal
PubMed Central and CAS, and is the official journal of The Society of Clinical Ophthalmology (SCO). The manuscript management system is completely online and includes a very quick and fair peer-review system, which is all easy to use. Visit http://www.dovepress.com/ testimonials.php to read real quotes from published authors. 